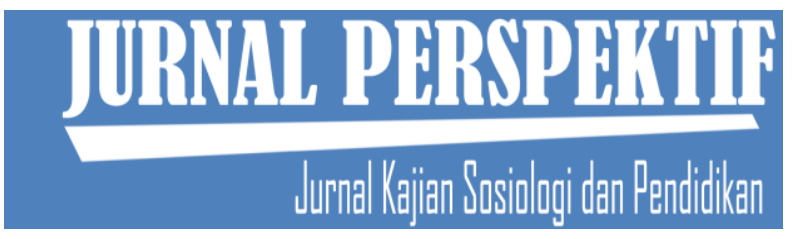

Jurnal Perspektif: Jurnal Kajian Sosiologi dan Pendidikan Vol. 4 No. 1 Tahun 2021

http://perspektif.ppj.unp.ac.id

Email: perspektif@ppj.unp.ac.id

ISSN: 2622-1748 (Online), 2684-902X (Print)

DOI: http://dx.doi.org/10.24036/perspektif.v4i1.405

\title{
Analisis Reward Dalam Organisasi Kemasyarakatan (Studi Kasus) Anggota Deen Give Foundation Kota Padang
}

\author{
Reza Novita ${ }^{1}$ Eka Vidya Putra ${ }^{2}$ \\ ${ }^{1,2}$ Universitas Negeri Padang \\ Email: rezanovita998@gmail.com, ekavidyaputra@gmail.com
}

\begin{abstract}
Abstrak
Penelitian ini dilatarbelakangi oleh eksistensi dari keberadaan Deen Give Foundation (DGF) yang merupakan organisasi kemasyarakatan yang memiliki visi untuk menyebarluaskan kebaikan. Dalam menjalankan aktivitas ini DGF menjadikan mahasiswa sebagai relawan dan sumber daya dari organisasi DGF itu adalah relawanya terbukti dengan dimulai dari pendanaan, pelaksanaan program kerja yang bertumpu kepada keanggotaan DGF. Menariknya anggota DGF ini ternyata Sebagian besarnya adalah mahasiswa yang secara notabene masih bergantung ke orang tua untuk memperoleh uang belanja. Dalam melakukan aktivitas organisasi orang akan beraktivitas dalam organisasi itu jika ada reward keuntungan yang mereka dapatkan. Menarik disini melihat apa keuntungan sebenarnya yang didapatkan oleh anggota DGF yang sebagian besar masih berstatus mahasiswa ketika beraktivitas dalam program kerja DGF. Penelitian ini akan menggunakan teori pertukaran sosial yang terkait tentang reward dari Peter Blau. Reward merupakan ganjaran atau penghargaan yang didaptkan oleh seseorang dari hasil pertukaran sosial yang dilakukan. Penelitian ini menggunakan pendekekatan kualitatif dengan jenis deskriptif yang dilakukan di organisasi Deen Give Foundation (DGF) Kota Padang. Teknik pemilihan informan adalah Purposive Sumpling. Tipe penelitian dengan studi kasus informan tujuh orang yang masih aktif dalam organisasi dan tiga orang pendiri DGF. Teknik pengumpulan data dengan cara observasi, wawancara mendalam, dokumentasi yang dianalisis menggunakan analisis Miles dan Huberman (Pengumpulan data, reduksi data, penyajian data dan verifikasi data). Reward yang mereka dapatkan berupa reward bersifat intrinsik dan ekstrinsik.
\end{abstract}

Kata Kunci: Deen Give Foundation, Organisasi, Reward

This research is motivated by the existence of the Deen Give Foundation (DGF) which is a community organization that has a vision to spread goodness. In carrying out this activity, DGF turns students into volunteers and the resources of the DGF organization are volunteers proven by starting from funding, implementing work programs that are based on DGF membership. It is interesting that most of the DGF members are students who in fact still depend on their parents for spending money. In carrying out organizational activities, people will be active in the organization if there is a reward for the benefits they get. most of them were still students when they were active in the DGF work program. This study will use the theory of social exchange related to the reward from Peter Blau. Reward is a reward or rewards that someone gets from the results of social exchanges that are carried out. This study used a qualitative approach with a descriptive type conducted in the Deen Give Foundation (DGF) Padang City organization. The informant selection technique is purposive sumpling. This type of research is a case study of seven informants who are still active in the organization and the three founders of DGF. The technique of collecting data by means of observation, in-depth interviews, and documentation which is analyzed using the analysis of Miles and Huberman (data collection, data reduction, data presentation and data verification). The rewards they get are intrinsic and extrinsic rewards.

Keywords: Deen Give Foundation, Organization, Organization 


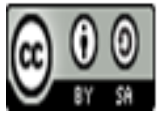

\section{Pendahuluan}

Deen Give Foundation (DGF) salah satu organisasi swadaya kemasyarakatan yang ada di Kota Padang. Organisasi didirikan pada tanggal 12 Juli 2012. Keberadaan DGF secara formal terdaftar dipemerintahan, tercatat dalam notaris dengan nomor 06/18-7-2012. Sekretariat organisasi terletak di Jalan Kakak Tua Nomor 2 A, Air Tawar Barat, Kota Padang. Namun alamat sekretariat diatas mulai dari tahun 2017 tidak ada lagi, sekarang mereka lebih memilih berkumpul di Mesjid Raya Sumatera Barat karena dapat meminimalisir biaya yang keluar untuk membayar sekre tersebut dan masih bisa dijadikan tempat perkumpulan untuk diskusi. Struktur organisasi dari DGF terdiri dari ketua, sekretaris, bendahara, koordinator Pendidikan, event dan sosial, koordinator humas dan koordinator relawan. Visi dari DGF adalah "menjadi lembaga sosial yang menyebarluaskan prinsip kebaikan di Indonesia". Adapun misi dari organisasi DGF adalah "memberikan dukungan bagi orang-orang kurang mampu untuk bisa bangkit, berbuat, dan menggapai keberhasilan yang diharapkan. Sehingga terbentuklah tujuan DGF yaitu (1) Untuk menebarkan kebaikan dan memberikan dukungan bagi orang-orang yang kurang mampu (2) Menghimpun potensi yang ada bersama-sama, menunjang pemerintah dalam menangani permasalahan sosial yang ada dalam masyarakat (3) Mempererat persatuan dan mempertebal rasa kekeluargaan para relawan (4) Membantu meringankan beban orang yang membutuhkan (5) Menciptakan relawan-relawan yang siap berbagi dimana pun berada.

Untuk merealisasikan tujuan organisasi, DGF melakukan sejumlah kegiatan yang dapat dikatakan sebagai program rutin. Berikut kegiatan yang rutin dilakukan oleh DGF adalah (1) Sekolah pemulung bagi anak-anak pemulung (2) Bimbel gratis untuk anak-anak panti asuhan

(3) Event diberbagai panti asuhan dengan pemberian motivasi dan melakukan beberapa outbound. (4) Pembagian nasi bungkus yang dilakukan setiap Jum'at malam oleh relawan DGF (Deen Give Foundation). Untuk menjalankan aktivitas organisasi sumber keuangan DGF berasal dari iyuran relawan dan sumbangan para donatur tidak tetap yang didapatkan sebelum kegiatan dilakukan. Semua anggota akan mempromosikan di sosial media atau mengajak orang lain untuk ikut serta secara sukarela menyumbang dana dalam melancarkan kegiatan DGF. Dana didapatkan dari anggota dan donatur rata-rata Rp.500.000-Rp 10.000.000., dan diserahkan kepada bendahara baik secara langsung atau melalui transfer, digunakan untuk kepentingan program pembagian nasi bungkus, event diberbagai panti asuhan dan event ketika pembekalan anggota DGF.

Paparan visi, misi, tujuan dan program kerja seperti yang disampaikan di atas merupakan wujud kolektif dari DGF. DGF dalam hal ini dapat dikelompokkan sebagai organisasi kemasyarakatan. Ciri dari organisasi kemasyarakatan adalah ia bersifat nonprofit dan berswadaya. Nonprofit artinya organisasi tersebut tidak berorientasi untuk mencari keuntungan secara ekonomi. Berswadaya dapat diartikan dalam menjalankan aktivitas organisasi ini tidak bergantung pada negara dan pasar. Secara kolektif apa yang dilakukan DGF jamak ditemui di berbagai organisasi kemasyarakatan lainnya. Namun ada yang menarik dari kasus DGF ini, secara kolektif DGF memiliki tujuan untuk berbagi kebaikan dengan masyarakat marjinal. Kebaikan tersebut dapat dilakukan secara material maupun non material. 
Untuk melaksanakan tujuan tersebut DGF bersandar pada sumber daya organisasi terhadap anggota yang sebagian besar anggota DGF adalah mahasiswa. Secara sosial anggota yang masih berstatus mahasiswa ini belum otonom, dan secara ekonomi masih jauh dari kata mandiri. Sedangkan anggota DGF merupakan tulang punggung dari DGF, sedangkan tuntunan DGF keanggotaan organisasi mengenai pembagian kerja dalam masyarakat dianalisis melalui solidaritas sosial menjelaskan pengaruh (atau fungsi) kompleksitas dan spesialisasi pembagian kerja dalam struktur sosial dan perubahan-perubahan yang diakibatkan dalam bentuk-bentuk pokok solidaritas. Hasil penelitian tersebut menunjukan bahwa nilainilai solidaritas sosial yang ditanamakan di dalam PLC kota payakumbuh yaitu adanya nilai kekeluargaan antar anggota PLC bukan hanya dirasakan antar anggota tapi masyarakat lainnya. Saling membantu antar anggota PLC dan masyarakat lainnya seperti anggota PLC yang terkena musibah atau membantu korban bencana. Melaksanakan musyawarah antar anggota setiap membuat aturan dan menyelesaikan masalah.

Penelitian selanjutnya dari Fauzan Ediz dengan judul "Perilaku Organisasi Anggota KSR UNIT PMI UNP”. Permasalahan tidak sesuainya perilaku anggota organisasi KSR UNP dengan ketentuan yang telah disepakati. Teori yangg digunakan untuk menganalisis teori ini menggunakan pemikiran Peter M. Blau tentang pertukaran sosial yang bertujuan memahami struktur sosial berdsarkan analisis proses-proses sosial yang mengatur hubungan antar individu dengan kelompok. Hasil penelitian faktor yang menyebabkan perilaku organisasi mahasiswa KSR PMI Unit UNP tidak sesuai dengan ketentuan-ketentuan yang ditetapkan bersal dari faktor internal yaitu kurangnya sosialisasi terhadap lingkungan KSR UNP dan kurangnya pembinaan yang berlanjut dan ekstrenal yaitu bentrok dengan jadwal kuliah dan ada kegiatan di luara KSR UNP.

Persamaan dari penelitian ini dengan penelitian yang telah dilakukan sebelumnya adalah memiliki objek yang sama yaitu organisasi dan meneliti anggota yang bergabung dalam organisasi tersebut. Namun yang membedakan dengan penelitian yang saya lakukan adalah faktor pendorong seseorang bergabung dalam organisasi Deen Give Foundation yang sumber utamanya adalah para relawan yang bergabung di DGF.

\section{Metode Penelitian}

Penelitian ini merupakan penelitian kualitatif yang dilakukan di dalam organisasi DGF (Deen Give Foundation) di Kota Padang. Penelitian ini dilakukan karena dana organisasi DGF berasal dari anggota yang dominan masih berstatus mahasiswa sehingga apa yang memotivasi anggota untuk bergabung kedalam organisasi. Penelitian ini menggunakan tipe penelitian studi kasus, Penelitian studi kasus satu strategi penelitian dan penyelidikan yang menyelidiki berbagai fenomena yang ada dikehidupan nyata secara mendalam dan keunikan dalam suatu penelitian. Informan adalah orang yang dimamfaatkan untuk memberikan informasi. Informan penelitian adalah sesuatu baik orang, benda ataupun lembaga (organisasi), yang sifat keadaanya ditelit(Sugiyono, 2014)i. Penelitian ini dilakukan secara purposive sampling, yaitu informan penelitian sesuai dengan kriteria peneliti butuhkann informan dalam penelitian ini adalah 3 orang pendiri DGF, dan 7 orang mahasiswa aktif sebagai relawan DGF(Sugiyono, 2020).Untuk memperoleh informasi lebih mendalam peneliti menggunakan metode pengumpulan data diantaranya:1) Observasi adalah suatu kegiatan atau aktivitas yang dilakukan dengan sengaja, sistematis mengenai fenomena- fenomena sosial dan gejala-gejala psikis untuk kemudian dilakukan pencatatan(Sugiyono, 2014). (2) Wawancara merupakan salah satu teknik yang digunakan untuk pengumpulan data penelitian(Sugiyono, 2012). (3) 
dokumentasi Pengumpulan data juga akan dilakukan dengan mengumpulkan semua dokumunetasi yang berhubungan dengan penelitian. Dokumentasi dapat diperoleh dari arsip DGF dan atau dari media Facebook, Instagram.

\section{Hasil dan Pembahasan}

Terdapat beberapa alasan seseorang bergabung ke dalam organisasi Deen Give Foundation (DGF) Kota Padang. Sebagian besar seseorang bergabung kedalam DGF awal mulanya di sarankan oleh teman dekat sehingga seiring waktu mereka mengikuti aktivitasaktivitas dalam organisasi tersebut, sehingga mereka tertarik untuk mengikuti organisasi DGF hal ini dibuktikan dari hasil wawancara yang dilakukan oleh peneliti informan Nandia Pitri mengatakan: "saya awal gabung ke DGF di sarankan oleh teman saya dan menceritakan tentang organisasi ini akhirnya saya bergabung dan betah dalam DGF". Hal serupa juga disampaikan oleh Sella Fitria "kak awalnya diajak teman kos untuk bergabung dan sampai sekarang masih bergabung karena tertarik dengan DGF”, dari itu terdapat beberapa alasan mereka tetap bergabung dengan DGF diantaranya:

\section{Organisasi Sosial}

Organisasi sosial merupakan lembaga masyarakat yang berorientasi terhadap kepentingan masyarakat yang dibangun secara sukarela tanpa mengambil kebutuhan finansial (Ganja:2017). Sebagian besar orang tertarik bergabung dengan DGF karena organisasi sosial, yang unik berbeda dengan organisasi lainnya Dalam organisasi DGF terdapat kegiatan berbagi kebaikan terhadap masyarakat yang kurang mampu sehingga termotivasi untuk bergabung ke dalam organisasi tersebut dan bisa menjadi sarana sebagai agen perubahan yang bermamfaat bagi orang lain. Niswatu Hasanah (23 tahun) pada tanggal 23 Desember 2020 berikut paparannya:

"...saya bergabung di dalam DGF karena organisasi nya sosial, saya suka berbaur dengan sosial dengan berbagi kebaikan ke orang yang membutuhkan, sehingga saya termotivai untuk bergabung ke dalam organisasi DGF..."

Hal serupa juga disampaikan oleh Jefri Naldi (23 tahun) sebagai anggota DGF pada tanggal 30 Desember 2020:

"...Jiko ditanyoan alasan abang gabuang dengan DGF dek tertarik dengan organisasi berbaur sosial nio berbagi kebaikan ka urang lain bermamfaat untuak urang lain yang membutuhkan..."

Artinya

“...Jika ditanyakan alasan abang gabung dengan DGF karena tertarik dengan organisasi sosial ingin berbagi kebaikan dan bermamfaat bagi orang lain yang membutuhkan..."

Hal serupa juga disampaikan oleh Riolin Putri (23 tahun) pada tanggal 4 Januari 2020 ia menyatakan:

“...Alasan akak ikuik DGF nio menebar kebaikan ka urang urang yang kurang mampu, karano akak marasoan selagi awak tu berbuat kebaikan ka urang lain semakin banyak yang ta bantu, setidaknya dari hal yang kecil...” 
Artinya

“...Alasan akak bergabung DGF mau berbagi kebaikan ke orang yang kurang mampu, karena akak merasakan selagi kita berbuat kebaikan ke orang lain semakin banyak orang lain yang terbantu, satidaknya dari hal yang keci..."

Dari apa yang disampaikan oleh informan diatas alasan seseorang bergabung kedalam DGF karena organisasi tersebut merupakan organisasi sosial yang terdapat kegiatan-kegiatan berbagi kebaikan untuk orang yang kurang mampu. Sehingga bisa menebarkan kebaikan ke orang-orang yang kurang mampu. Semakin banyak berbagi kebaikan semakin banyak masyarakat yang terbantu ekonominya dan anggota DGF menjadi agen perubahan untuk masyarakat yang kurang mampu.

\section{Mencari Pengalaman}

Alasan seseorang bergabung dengan DGF mencari pengalaman baru dengan orangorang yang baru karena ingin mengembangkan diri bertemu dengan orang-orang baru sehingga menciptakan pemikiran yang terbuka, lebih percaya diri, menemukan wawasan yang luas sehingga keluar dari zona nyaman. Melalui bekal pengalaman yang telah didaptkan dalam organisasi Mencari pengalam didalam organisasi juga peluang bagi anggota untuk mendapatkan referensi ketika tamat dalam dunia perkuliahan. Mencari pengalaman dalam sebuah organisasi seorang mahasiswa dapat memahami dan mengetahui ilmu tentang keorganisasian (Jati, 2015) . Seperti yang disampaikan Yoga Yowanda (22 tahun) tanggal 5 januari 2020 menyatakan:

“...Awak bagabuang organisasi DGF untuak mencari menciptakan pemikiran lebih luas bia bisa lebih picayo diri nio bergaul dengan urang lain, dek awak pun sanang mencari hal-hal yang baru yang alun panah awak cuboan..."

Artinya:

“...Saya bergabung organisasi DGF untuk mencari pemikiran lebih luas untuk lebih percaya diri bergaul dengan orang lain, karena saya pun senang mencari halhal yang baru yang belum pernah saya cobakan sebelumnya..."

Hal serupa juga disampaikan oleh Nandia Pitri melalui wawancara daring tanggal 23 Desember 2020 menyatakan:

“...Kalau menanyakan alasan saya bergabung dengan DGF yaa ingin memperdalam pengalaman saya mengenai organisasi sosial, supaya saya bisa memahami lingkungan masyarakat ..."

Berdasarkan hasil wawancara dari Yoga Yowanda dan Nandia Pitri alasan seseorang bergabung ke dalam DGF untuk mencari pengalaman di dalam organisasi berbaur masyarakat sehingga terciptanya pemikiran yang luas yang didapatkan di luar kampus, mengembangkan pengembangan baru, lebih percaya diri karena mendapatkan orang-orang yang baru sehingga bisa menjadi peluang untuk mendapatkan referensi di organisasi DGF dan memahami tentang organisasi sosial.

\section{Menambah Pertemanan}

Organisasi DGF terdiri dari anggota yang berasal dari latar belakang perguruan tinggi yang berbeda sehingga akan menjadi dekat dengan anggota organisasi DGF. Menambahkan pertemanan merupakan salah satu alasan mereka bergabung dengan organisasi yaitu untuk memperluas relasi di luar kampus, sehingga mendapatkan kegiatan yang banyak untuk 
mengisi waktu luang dan bisa menghargai waktu. Menambahkan pertemanan juga membaut mahasiswa merasa nyamanmengikuti suatu organisasi bisa menadapatkan banyak teman(Sexton et al., 2018) . Hal ini dibuktikan melalui wawancara Riolin Putri Artiwi (23 tahun) pada tanggal 4 Januari 2020 menyatakan:

“...Alasan akak ikuik DGF nio manambah an organisasi akak di lua kampus, banyak organisasi banyak lo kegiatan akak di Padang, semakin banyak organisasi semakin banyak dapek kawan ma, karano melalui kawan-kawan baru awak tu bisa mandapek an ahal-hal yang baru apalagi mahasiswa yang berasal dari daerah yang berbeda..."

\section{Artinya}

“...Alasan akak gabung DGF ingin menambahkan organisasi luar kampus, karena banyak organisasi banyak juga kegiatan akak di Padang, semakin banyak organisasi semakin banyak dapat teman, karena melalui teman baru kita bisa mendapatkan halhal yang baru apalagi mahasiswa yang berasal dari daerah yang berbeda ..."

Hal serupa juga Disampaikan oleh Sella Fitria (23 tahun)

“... Alasan kak ikut organisasi DGF simpel, ingin mencari suasana baru di luar kampus, ingin menambahkan suasana pergaulan di luar kampus, semakin banyak relasi didalam organisasi semakin banyak hal-hal yang baru didapatkan..."

Berdasarkan hasil wawancara Riolin Putri Artiwi dan Sella Fitria bahwa alasan seseorang bergabung ke dalam DGF karena ingin menambahkan pertemanan untuk memperluaskan relasi diluar kampus, banyak teman banyak mendapatkan relasi apalagi anggota DGF berasala dari kalangan mahasiswa yang latar belakang daerah yang berbeda. Semakin banyak pertemanan di luar kampus, semakin banyak mendapatkan hal-hal yang baru yang belum ditemukan sebelumnya, sehingga mendapatkan suasana baru yang tidak didapatkan didalam organisasi kampus.

\section{Memperluas Wawasan}

Organisasi DGF dapat menjadi sarana untuk bersosialisasi dengan orang-orang baru. Didalam organisasi DGF juga merupakan wadah untuk melatih setiap anggota agar memiliki kemampuan. Setiap orang bergabung dalam suatu organisasi memeiliki alasan masingmasing. Beberapa anggota DGF menjelaskan motivasi bergabung dalam organisasi tersebut untuk mencari wawasan yang luas, karena didalam organisasi terdapat suatu aktivitasaktivitas yang baru. Seperti yang diungkapkan oleh Yoga Yowanda (22 tahun) pada tanggal 5 Januari 2021 menjelaskan:

“...Awak bagabuang organisasi DGF untuak menciptakan pemikiran yang luas nio mancari suasana baru di lua organisasi kampus..."

Artinya:

“...Saya bergabung organisasi DGF untuk menciptakan pemikiran yang luas, mencari suasana baru di luar organisasi kampus..."

Ungkapan lain juga disampaikan oleh Novelin (22 tahun) 
“...Jika ditanya alasan saya bergabung ke dalam DGF, saya tu mau mencari relasi dalam sebuah organisasi baru di luar kampus, ingin mendapatkan sesuatu hal yang baru karena organisasi sosial tidak ada di dalam kampus..."

Berdasarkan hasil wawancara peneliti dari informan diatas alasan mereka bergabung organisasi DGF memperluas wawasan, sehingga kemampuan seseorang terasah, mendapatkan kegiatan-kegiatan yang belum ditemukan di dalam organisasi kampus, sehingga mendapatkan wawasan yang menarik didalam organisasi DGF. Semakin banyak wawasan yang didapatkan maka akan semakin banyak wawasan yang didapatkan dari organisasi DGF.

\section{Reward yang didapatkan di Organisasi}

Dalam kehidupan manusia segala sesuatu akan dicari dalam mendapatkan kesenangan dalam relasi sosial mereka. Orang akan lebih betah dan sesuai ketika orang lain yang mengesahkan dirinya(Wirawan, 2012). Dalam setiap hubungan sosial akan ada suatu unsur sebab-akibat, berbentuk ganjaran, pengorbanan bahkan reward yang di pertukarkan dalam suatu organisasi(Ritzer George, 2010). Blau mengatakan setiap orang melakukan sesuatu pasti ingin mendapatkan sesuatu. Bahkan seseorang rela mengeluarkan biaya untuk mencapai suatu reward uang. Berikut reward yang diperoleh anggota bergabung dalam organisasi DGF:

\section{Penghargaan}

Reward yang didapatkan seeorang ketika bergabung dalam sebuah organisasi tidak hanya berupa uang ataupun barang tetapi ada juga berupa penghargaan psikis disebut juga dengan reward simbolik. Berdasarkan hasil penelitian informan reward yang didapatkan oleh seseorang bergabung kedalam organisasi DGF ialah mendapatkan sebuah penghargaan psikis seperti suatu pujian, atau berupa penghormatan dari masyarakat. Sehingga angggota menumbuhkan komitmen terhadap organisasi meskipun memberikan pengorbanan berupa materi ataupun tenaga karena seseorang merasa puas terhadap pengakuan dirinya didalam suatu masyarakat(Prabu \& Wijayanti, 2016). Seperti yang diungkap dari hasil wawancara informan dibawah ini:

Hasil wawancara yang disampaikan oleh Niswatu Hasanah (23 tahun) secara daring tanggal 23 desember 2020:

“...kakak meraso dihargai dek masyarakat dan ado raso perhatian yang didapek an, itu yang mambuek kak semakin semangat, selamo awak bisa menebar kan kebaikan selamo itu kak bahagia..."

Artinya

“...kakak merasa dihargai oleh masyarakat dan mendapatkan perhatian, dan membuat kakak semakin semangat menebarkan kebaikan walaupun mengeluarkan uang untuk kegiatan berbagi. Selama kita bisa menebarkan kebaikan selama itu kakak bahagia..."

Hal serupa seperti di ungkapkan oleh Nandia Pitri (22 tahun) tanggal 23 Desember 2020:

"...Selama saya mengikuti program DGF saya merasa dihargai oleh masyarakat, masyraakat ramah dengan saya, selalu tersenyum ketika saya datang. Disambut dengan wajah yang bahagia oleh masyarkat setempat Saya merasa berharga bagi orang lain..."

Dari ungkapan yang disampaikan oleh Niswatu Hasanah reward yang diharapkan mereka bukan berupa material tetapi berupa reward kepuasan berupa penghargaan yang didapatkan dari masyarakat setempat setelah anggota tersebut berbagi ke masyarakat kurang 
mampu selama bergabung dalam DGF, dengan dihargai oleh masyarakat setempat mereka semakin termotivasi untuk secara terus menerus melakukan kegiatan-kegiatan DGF. Walaupun mereka mengeluarkan materi untuk melancarkan program organisasi DGF.

\section{Kebersamaan}

Manusia sebagai makhluk sosial membutuhkan orang lain untuk keberlangsungan hidup, melalui kebersamaan individu bisa mengenal jati diri, merasa damai dan bisa mendapatkan gerbang kesuksesan. Kolektifitas merupakan sikap yang tertanam dalam diri pribadi seseorang yang memiliki kebrsamaan dalam melakukan segala sesuatu hal (Jamil, 2014) .Berger dan Luckman juga menyatakan manusia menyempurnakan kehidupannya melalui kebersamaan (Tirtawinata, 2013). Di dalam DGF ada suatu integrasi yang terbentuk dari interaksi hubungan sosial walaupun anggota berasal dari latar belakang yang berbeda. Sehingga mendorong seseorang rela berkorban berupa materi untuk melancarkan kegiatan DGF karena mendapatkan suatu reward dari pertukaran sosial didalam organisasi tersebut. Hal ini dibuktikan dari hasil wawancara dari informan. Seperti yang diungkapkan oleh Noveline Patricia Damanik tanggal 22 Desember 2020 (22 tahun) melalu wawancara daring berkata:

“... saya merasakan ada rasa ikatan kekeluargaan yang erat antar anggota yang saya rasakan dalam DGF apalagi keluarga saya jauh dari Medan ke Padang, karena selama saya bergabung dengan DGF saya mengenal anggota-anggota tersebut dan ketika saya ada kendala di Padang saya di bantu oleh anggota DGF..."

Hal ini juga diungkap oleh Niswatu Hasanah (23 tahun) pada tanggal 23 Desember 2020 berikut paparanya:

“...Yang akak dapatkan selama bergabung dengan DGF hal yang nggak akak dapatkan dari organisasi lain yang pernah kakak ikuti, melalui kedekatan dengan anggota, akak merasa nyaman dengan anggota, bisa bercanda gurau, kalau udah ngumpul dengan anggota DGF lepas rasanya berbicara di DGF walaupun berbeda asal kampus..."

Hal serupa juga diungkapkan oleh anggota DGF Nandia Pitri melalui wawancara daring tanggal 23 Desember 2020 menyampaikan:

“... yang saya dapatkan dalam DGF rasa kebersamaan antara anggota hal itu terasa disaat kami event dan melaksanakan kegiatan DGF tidak ada membeda-beda kan di dalam DGF, semua seperti keluarga sendiri..."

Berdasarkan dari penjelasan wawancara yang disampaikan Niswatu Hasanah, Novelin Patricia Damanik dan Nandia Pitri reward yang didapatkan selama bergabung dalam organisasi DGF yaitu nilai-nilai kolektif seperti rasa kebersamaan yang dirasakan antar anggota walaupun berasal dari latar belakang kampus yang berbeda dan nilai-nilai kekeluargaan yang didapatkan oleh anggota tersebut yang bisa membuat erat hubungan antar anggota.

\section{Mengembangkan Soft Skill}

Soft skill merupakan kemampuan yang berasal dari dalam diri seseorang yang bisa mengembangkan percaya diri terhadap seseorang(Rusdianti, 2018). Ketika bergabung dengan 
sebuah gerakan sosial, ada suatu hal yang tidak bisa di prediksikan sebelumnya seperti ada kesempatan mengembangkan kepercayaan diri untuk mengajar. Putra dan Pratiwi (2005) menyatakan bahwa soft skill yang dibutuhkan oleh lulusan universitas tidak dapat hanyak didapatkan dalam proses pembelajran tetapi juga bidang non akademik (Rusdianti, 2018). Sebuah organisasi dapat memberikan kesempatan mengembangkan diri ke lebih baik, salah satunya organisasi DGF. Didalam DGF terdapat program sekolah pemulung dan bimbel gratis untuk anak pemulung dan panti, melalui program tersebut bisa mengembangkan soft skill untuk mengajar. Seperti yang diungkap anggota DGF Jefri Naldi melalui wawancara daring tanggal 30 desember 2020:

"... Imbalan yang abang dapek an salamo gabuang dengan DGF yang abang rasoan, madapek an peluang untuk mengajar ilmu yang abang punyo ka urang lain dengan hal begitu secara tidak langsung ilmu yang abang dapek an salamo menuntut ilmu bisa di kembangkan, ndak mati di jalan, salamo abang mengajar di sekolah pemulung semakin pacayo diri abang untuak mengajar..."

Artinya

“...Imbalan yang abang dapatkan selama bergabung dalam DGF yang saya rasakan mendapatkan peluang mengembangkan ilmu yang abang punya ke orang lain dengan hal begitu secara tidak langsung ilmu yang abang dapatkan selama menuntut ilmu bisa dikembangkan tidak hanya mati di jalan, selama abang mengajar disekolah pemulung semakin percaya diri untuk mengajar...”

Hal serupa juga disampaikan oleh Riolin Putri Artiwi (22 tahun) pada tanggal 4 januari 2021 mengatakan:

“.. Hal yang awak dapek an salamo bagabung DGF sesuatu yang unik, waktu wak mengikuti program sekolah pemulung awak bisa belajar mengajar ka urang lain ilmu yang wak dapek an salamo iko pun bisa dikembangkan di program tu..."

Artinya:

“...Hal yang saya dapatkan selama bergabung DGF sesuatu yang unik, waktu saya mengikuti program sekolah pemulung kita bisa belajar mengajar ke orang lain, ilmu yang kita dapatkan selama ini pun bisa dikembangkan diprogram itu..."

Berdasarkan hasil wawancara dari Jefri Naldi dan Riolin Putri Artiwi dapat disimpulkan meskipun mereka rela berkorban mengeluarkan jasa untuk menjalankan program DGF karena mereka mendapatkan reward yang didapatkan selama bergabung dalam DGF yaitu berupa pengembangan soft skill didalam program sekolah pemulung dan bimbel gratis sehingga kesempatan tersebut bisa dimamfaatkan untuk mencari pekerjaan setelah tamat dari dunia perkuliahan setelah pelatihan diri di program DGF tersebut seperti pelatihan mengajar, cara berkomunikasi dengan baik dan pelatihan untuk kemantalan diri didepan khalayak banyak.

\section{Mendapatkan Relasi}

Bergabung ke dalam organisasi pasti akan mendapatkan orang-orang baru. Apalagi organisasi yang berada di luar kampus, seperti organisasi DGF yang memiliki anggota yang berasal dari latar belakang yang berbeda baik itu kampus yang berbeda, asal daerah dan latarbelakang kepribadian yang berbeda. Membangun relasi juga mendapatkan pengaruh positif bagi seseorang(Caesari et al., 2013). Sehingga alasan seseorang untuk bergabung 
kedalam organisasi DGF mendapatkan teman baru untuk mendapatkan koneksi lebih banyak. Seperti diungkapkan oleh anggota DGF Yoga Yowanda (22 tahun) pada tanggal 5 Januari 2021:

“...Yang awak dapek an bagabung dalam DGF ko relasi, semakin banyak kawan wak semakin Panjang koneksi bakawan wak Panjang, banyak kawan banyak peluang yang wak dapek an, yang mambuek wak tetap semangat tu dapek kawan lebih banyak..."

Artinya:

“...Yang saya dapatkan dalam DGF teman yang banyak sehingga koneksi pertemanan Panjang, banyak teman banyak peluang yang didapatkan, yang membuat saya semangat mendapatkan teman banyak..."

Dari penjelasan wawancara diatas yang disampaikan oleh Yoga Yowanda 22 tahun dapat kita ketahui reward yang didapatkan dalam organisasi DGF yaitu menambahkan relasi baru untuk mendapatkan peluang untuk mendapatkan koneksi setelah tamat didunia perkuliahan, karena dia merasa semakin banyak jaringan pertemanan semakin banyak jaringan untuk mengetahui kesempatan peluang bekerja.

\section{Religi}

Semua manusia akan hidup sesuai dengan ajaran agama masing-masing yang di ajaran agama masing-masingsehingga akan terbentuk suatu kerukunan, kedamain, atau sesuatu hal yang baik dalam kehidupan masyarakat karena agama mengajarkan kita tentang kebenaran untuk kehidupan(Bauto, 2016). Sebagaiamana yang di katakana oleh Karl Marx agama adalah candu, bahwa agama suatu kepercayaan yang memiliki aturan dan ganjaran yang harus di patuhi oleh pengikutnya(Farihah, 2015). sehingga seseorang termotivasi untuk berbuat kebaikan secara sukarela atau dikenal dengan istilah ikhlas, Seorang melakukan sesuatu karena ingin mendapatkan imbalan tidak berupa materi tetapi juga in materi seperti berupa reward dari Tuhan Yang Maha Esa. Seperti yang di ungkapkan oleh Jefri Naldi pada tanggal 30 Desember 2020:

“...Hal yang abang dapek dari DGF pahalo, kalau awak babagi kebaikan ka urang lain imbalannyo pahalo yang wak dapek an sebagai celengan untuak di akhirat kelak, itu yang utamo abag kaja an di DGF..."

Artinya

“...Hal yang abang dapatkan dari DGF berupa pahala, kalau kita berbagi kebaikan ke orang lain imbalannya pahala yang kita dapatkan sebagai celengan untuk di akhirat kelak, itu yang abang cari di DGF..."

Hal serupa juga disampaikan oleh Niswatu Hasanah (23 tahun) pada tanggal pada tanggal 23 Desember 2020 berikut paparanya:

“... Hal yang paling utama yang saya dapatkan keridoan Allah, karena lelah saya akan hilang jika saya mendapatkan keridoan Allah untuk akhirat saya nantinya, Allah juga mengajurkan kita untuk hablumminannas..." 
Reza Novita, Eka Vidya Putra

Analisis Reward Dalam Organisasi Kemasyarakatan

(Studi Kasus) Anggota Deen Give Foundation Kota Padang

Hal serupa juga disampaikan oleh Nandia Pitri melalui wawancara daring tanggal 23 Desember 2020 menyatakan:

“...Saya mendapatkan pahala dari apa yang saya lakukan dengan secara ikhlas, karena agama juga mengajurkan kita untuk berbagi terhadap sesame manusia, semakin banyak kita berbuat kebaikan kepada manusia semakin banyak pahala yang didaptkan..."

Dari hasil wawancara yang telah dilakukan peneliti salah satu reward yang didapatkan oleh anggota didalam organisasi DGF adalah mendapatkan reward dari Tuhan Yang Maha Esa. Karena adanya kepercayaan religi bahwa semua kebaikan yang diperbuat didunia akan mendapatkan reward di akhirat. Semakin banyak berbuat kebaikan ke orang lain didunia semakin banyak pahala yang didapatkan. Ketika seseorang berbagi kebaikan maka akan mendapatakan suatu kepuasan batin yang didapatkan seseorang. Seseorang akan rela mengeluarkan hal yang bersifat materi untuk mendapatkan suatu kepuasan batin.

\section{Analisis Teori}

Penelitian ini dianalisis menggunakan teori dari Peter Blau. Teori ini menyatakan bahwa pertukaranitu terjadi antara individu dan organisasi, suatu pertukaran terjadi apabila adanya suatu interaksi didalam organisasi. Seseorang melakukan sesuatu karena mengharap sesuatu (rewatd). Hal ini dapat dilihat dalam organisasi DGF yang mana didalam organisasi tersebut terdapat suatu pertukaran sosial anta individu dengan DGF. Bukti nyatanya seperti anggota DGF menjadi relawan dan berbagi kebaikan untuk masyarakat yaitu dengan cara:

Memberikan ilmu, tenaga, dan juga waktu secara gratis kepada anak pemulung dan Panti Asuhan di Kota Padang. Dari apa yang diberikan oleh anggota DGF berupa ilmu, tenaga dan waktu maka mereka mendapatkan pengalaman mengajar yang bisa dijadikan sebagai untuk bekerja setelah tamat kuliah dan juga mendapatkan pahala sebagai imbalan religi dari atas kebaikan yang telah dilakukan oleh anggota seperti kegitan yang dilakukan dalam program sekolah pemulung, bimbel gratis di panti asuhan dan event di Panti Asuhan.

Anggota memberikan materi berupa uang untuk dikumpulkan membeli nasi bungkus yang akan dibagikan kepada masyarakat Kota Padang yang kurang mampu namun masih berusaha seperti pemulung, pedagang kecil keliling yang lansia dan orang gila. setiap hari jum'at malam 1 kali dalam dua mingu. Dari apa yang diberikan oleh anggota DGF maka mereka mendapatkan reward berupa penghargaan psikis seperti disenangi oleh masyarakat dapat dilihat dari keramahan masyarakat dalam menyambut anggota DGF datang ke lokasi. Disinilah terjadi pertukaran sosial antara anggota DGF dengan masyarakat.

Anggota memberikan uang, waktu dan tenaga fisik untuk melancarkan program DGF dari berbagai program organisasi tersebut maka seseorang mendapatkan relasi yang lebih luas

karena anggota DGF memiliki anggota dalam jumlah yang banyak dan berasal dari latar belakang daerah dan perguruan tinggi yang berbeda. Sehingga menimbulkan rasa solidaritas antar anggota dan kebersamaan dari setiap anggota DGF seperti ketika ada kendala kendaraan anggota yang mau ikut dalam melaksanakan kegiatan maka anggota tersebut akan dijemput oleh anggota yang memiliki kendaraan dan ketika anggota yang sakit maka akan dijenguk oleh anggota lain.

Dari penjelasan diatas dapat disimpulkan bahwa pertukaran sosial yang terjadi dalam sebuah organisasi DGF akan mendapatkan reward yang bersifat intrinsik dan ekstrinsik; (a) Intrinsik: Reward yang didapatkan oleh anggota dalam organisasi DGF berupa (penghargaan psikis, nilai-nilai kebersamaan, nilai religi) dalam program DGF yaitu program sekolah 
pemulung, bimbel gratis, event di panti asuhan dan program pembagian nasi bungkus. (b) Ekstrinsik; Reward yang diperoleh anggota dari hasil pertukaran sosial selama bergabung ke dalam organisasi DGF berupa reward (kesempatan mengembangkan soft skill) dengan memberikan ilmu pengertahuan, waktu dan tenaga kepada anak-anak pemulung dan anak Panti Asuhan.

\section{Kesimpulan}

Alasan seseorang bergabung dalam organisasi DGF yaitu karena DGF merupakan organisasi sosial, mencari pengalaman berorganisasi, menambahkan teman di dalam organisasi luar kampus, memperluas wawasan alasan. Peneliti menemukan bahwa seseorang termotivasi bergabung ke dalam organisasi DGF karena adanya nilai-nilai pertukaran sosial dari hasil interaksi sehingga adanya hubungan sosial antar individu ataupun kelompok berupa reward yaitu reward-intrinsik intrinsik berupa penghargaan psikis, dan kebersamaan dan rewardektriksik berupa mendapatkan relasi dan mengembangkan soft skill sehingga anggota bisa mengembangkan kemampuan, ide, fikiran, atau keterampilan seperti program DGF memberikan bimbel gratis ke pemulung dan panti asuhan, memberikan ilmu dalam program sekolah lentera, dan memberikan skill ke anak-anak pemulung mengolah sampah menjadi suatu yang berharga: pembuatan tirai dari plastik dan menggunakan kotak sampah sebagai alat hitung dalam belajar.

\section{Daftar Pustaka}

Herdiansah, A. G. (2016). Peran organisasi masyarakat (Ormas) dan lembaga swadaya masyarakat (LSM) dalam menopang pembangunan di Indonesia. Sosioglobal: Jurnal Pemikiran dan Penelitian Sosiologi, 1(1), 49-67.

Bauto, L. M. (2016). Perspektif Agama dan Kebudayaan Dalam Kehidupan Masyarakat Indonesia (Suatu Tinjauan Sosiologi Agama). Jurnal Pendidikan Ilmu Sosial, 23(2), 11. https://doi.org/10.17509/jpis.v23i2.1616

Caesari, Y. K., \& Listiara, A. (2013). "Kuliah versus organisasi” studi kasus mengenai strategi belajar pada mahasiswa yang aktif dalam organisasi mahasiswa pecinta alam universitas diponegoro. Jurnal Psikologi, 12(2), 164-175.

Farihah, I. (2015). Filsafat materialisme Karl Marx (Epistimologi Dialectical and Historical Materialism). Jurnal Ilmu Aqidah Dan Studi Keagamaan, 3(2), 431-458.

Jamil, O. M. (2014). Pentingnya Membangun Kolektifitas (Kebersamaan). https://osf.io/hzafu

Jati, S. M. U. (2018). Jurnal Motivasi dan Kebermaknaan Berorganisasi Pada Mahasiswa Universitas Muhammadiyah Surakarta. Disertasi. Universitas Muhammadiyah Surakarta.

Prabu, A. S., \& Wijayanti, D. T. (2016). Pengaruh Penghargaan dan Motivasi Terhadap Kinerja Karyawan (Studi Pada Divisi Penjualan PT. United Motors Center Suzuki Ahmad Yani, Surabaya). Jurnal Ekonomi Bisnis Dan Kewirausahaan, 5(2), 104. https://doi.org/10.26418/jebik.v5i2.17144

Ritzer, G. (2010). Teori Sosiologi Modern. Jakarta: Prenada Media Group.

Rusdianti, F. (2018). Pengalaman Berorganisasi dalam Membentuk Soft Skill Mahasiswa. Jurnal Pendidikan dan Ilmu Sosial, 28(1), 58-65.

Sugiyono, S. (2012). Metode Penelitian Kualitatif Dan R\&D. Bandung: Afabeta. 
Tirtawinata, C. M. (2013). Mengenal dan Menemukan Diri melalui Kebersamaan dengan Orang Lain. Humaniora, 4(2), 13. https://doi.org/10.21512/humaniora.v4i2.3575

Wirawan, W. (2012). Teori-Teori Sosial Dalam Tiga Paradigma. Jakarta: Kencana Perdamedia Group. 